\title{
CD33 Negative
}

National Cancer Institute

\section{Source}

National Cancer Institute. CD33 Negative. NCI Thesaurus. Code C162066.

An indication that CD33 expression has not been detected in a sample. 